\title{
The Effect Of Corporate Governance On Unfaithful Disclosure Designation And Unfaithful Disclosure Penalty Points
}

Bo Young Moon, Dankook University, South Korea

Soo Yeon Park, Korea University, South Korea

\begin{abstract}
This paper investigates the relation between Unfaithful Disclosure Corporations ("UDC") and corporate governance using listed firm (KOSPI and KOSDAQ) data in Korea. Prior literature reports that corporate governance has an impact on the level of disclosure and the quality of disclosure provided by companies. However, it is hard to find the studies about corporate governance and UDC at the term of disclosure quality. Compare to some financially advanced countries, Korea established corporate governance in a relatively short period of time; hence concerns have been raised the corporate governance have not played effective role to monitor management. We question how corporate governance affects companies' unfaithful disclosure by using several corporate governance proxy variables and UDC data which is unique system in Korea.

From the empirical tests, we find a negative association between the proportion of outside directors, an indicator of the board's independence, and UDC designation, among companies listed on both KOSPI and KOSDAQ. On the other hand, there is a significant positive association between the proportion of outside directors and UDCs' imposed and accumulated penalty points among KOSDAQ-listed companies. This implies that outside director system effectively play a monitoring role however due to different natures of members included in outside directors, the system often fails to control regarding based reasons for penalty points imposition. In addition, we find the percentage of foreign equity ownership showed statistically significant positive association with UDC designation and a significant positive association with the imposed and accumulated penalty points among KOSPI-listed companies. We interpret this results that foreign investors with a short-term investment propensity may not enough to play a proper monitoring role in Korea and thereby they cannot effectively control the disclosure quality provided by the management. We also find that there is a significant positive association between the percentage of managerial ownership and UDC designation in the KOSDAQ market.
\end{abstract}

This study will contribute to academics and disclosure-related practitioners by documenting about corporate governance and its impact on unfaithful disclosure corporations.

Keywords: Corporate Governance; Outside Directors; Foreign Investors; Management Ownership; Unfaithful Disclosure Corporation

\section{INTRODUCTION}

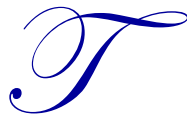

he purpose of this study is to analyze the relationship between Unfaithful Disclosure Corporations ("UDC") and corporate governance. In particular, to understand the link between corporate governance and UDC designation/imposition of penalty points, we explored how corporate governance affects companies' unfaithful disclosure, by using and measuring the percentage of outside directors, the percentage of foreign ownership and that of managerial ownership as proxy variables.

Mandatory and voluntary disclosure are the useful channels for outside information users to access companies' financial information; thus, they decrease information asymmetry. Timely and accurate disclosure allows an efficient allocation of resources. However, if disclosure is not transparent, containing overstated, understated or hidden 
information in it, information users cannot make reasonable decisions based on such unreliable source of information. Also, if managers attempt to present misleading information out of their opportunistic considerations or for ulterior motives, information users would end up suffering losses. Hence, regulatory measures are necessary to ensure that companies disclose information fairly and accurately, causing no confusion to the capital market.

To this end, Korea Exchange came up with a regulation to designate UDCs if listed companies 1) fail to comply with the Securities Exchange Act and the disclosure obligation by Korea Securities and Futures Exchange, and 2) breach the disclosure obligation, i.e., perform non-disclosure, reversal or alteration of disclosed information; companies falling under the above category are designated as UDCs ${ }^{1}$ and placed under the supervision of Korea Exchange. UDCs are subject to certain penalty measures ranging from trading suspension, prevention education, designation as administrative issue, request for submission of improvement plan to delisting; such measures are determined depending on the severity of unfaithful disclosure behavior. UDCs may also be subject to a fine of up to KRW 200 million and imposition of penalty points. Trading for UDCs with 5 penalty points or more is suspended for one trading day, and if UDCs have accumulated 15 penalty points or more within a year, it is designated as administrative issue. And if an administrative issue receives 15 accumulated penalty points or more within one year after receiving the administrative issue, it shall receive a listing maintenance review. Being designated as UDCs means that errors exist in timeliness, accuracy and reliability of disclosed information; thus, the higher accumulated penalty points are, the more severe the breach of disclosure is. As Korea Exchange and securities brokers provide public announcement for UDC designation, reasons for designation and penalty points on their online system, unfaithful disclosure is believed to bring immediate and negative consequences to UDCs, such as bad impression and loss of reputation. ${ }^{2}$

Corporate governance is a system used to supervise and monitor companies' business in an independent manner; its purpose is to curb managers' opportunistic behavior and maximize ultimate shareholder value. In Korea, corporate governance emerged as a key management issue in the aftermath of the financial crisis in the late 1990s. Since then, Korean companies have shown remarkable improvement in corporate governance, as diverse efforts have been made to promote management transparency and healthy economic growth. In fact, a few research in the field of finance and accounting proved that good corporate governance leads to increased level of disclosure (Lee \& Sohn, 2005; Lee, Shim \& Choi, 2012).

In general, good corporate governance plays an effective role in monitoring and supervising management actions; this leads to better decision making by the management, and information risks faced by shareholders and agency costs are consequently mitigated (Ashbaugh, Collins \& LaFond, 2006; Byun, Kwak \& Hwang, 2008). In the Korean business community, however, concerns have been raised that the outside director system and foreign ownership, the most common forms of corporate governance, have not been effective enough to monitor management actions. Unlike some financially advanced countries, Korea established corporate governance in a relatively short period of time as a mechanism to cope with external factors; creating a regulatory framework was the main concern, so companies do not always feel the intended benefit of adopting corporate governance. In addition, in Korea, outside directors are mostly appointed on the recommendation of the majority shareholder or incumbent managers, making the outside director system less independent and less capable (Lee, Park, \& Choi 2001). In terms of foreign investment, some foreign investors' extreme profiteering has been frowned upon, i.e., foreign investors ask for higher dividends by taking advantage of their right as a large shareholder, and focus on short-term profit harvesting and predatory investment strategy. As such, we believed an empirical analysis would help us understand whether corporate governance prevents unfaithful disclosure by monitoring managers' opportunistic considerations and ulterior motives and capturing errors in financial disclosure. In our empirical analysis, we used the proportion of outside directors, the percentage of foreign ownership and that of managerial ownership as proxy variables; using such variables, we explored whether corporate governance has a positive or negative influence on UDC designation and imposition of penalty points. Prior studies have been limited to explaining the relationship between corporate governance and the level of disclosure, measured by the frequency of disclosure, due to data insufficiency; our work takes a more detailed look, with our focus on explaining the relationship between corporate governance and UDC designation and accumulated penalty points.

\footnotetext{
${ }^{1}$ Companies may be designated as UDCs not only if their annual reports do not comply with the disclosure obligation, but also if their timely disclosure, fair disclosure, inquired disclosure and voluntary disclosure breach the obligation.

${ }^{2}$ Lee, Park and Lee (2014) observed the capital market reaction concerning UDC designation and imposition of penalty points. Their study shows that responses from the capital market were more negative when UDCs have higher penalty points.
} 
An empirical analysis of companies listed on KOSPI and KOSDAQ from 2000 to 2015 as to the correlation between corporate governance and UDC designation/penalty points produced the following results. First, there was significant negative association between the proportion of outside directors, an indicator of the board's independence, and UDC designation, among companies listed on both KOSPI and KOSDAQ. This implies that outside director system checks and balances the management, thereby effectively playing the role of reducing errors in timeliness, accuracy and reliability of disclosed information. On the other hand, we could find a significant positive association between the proportion of outside directors and UDCs' imposed and accumulated penalty points among KOSDAQ-listed companies. This mixed result seems to be attributable to different natures of members included in the proportion of outside directors. A board of directors ("BOD") is composed mainly of inside directors, grey directors and outside directors (Baysinger \& Butler 1985). Grey directors are those who are counted in the proportion of outside directors as they technically do not take part in the management, but in fact not independent from the firm or the management. Due to the unique nature of Korea's BOD composition, represented by interests or school ties ${ }^{3}$, the outside director system often fails to control the situation which leads the UDCs to receive penalty points. Second, the percentage of foreign equity ownership showed statistically significant positive association with UDC designation and a significant positive association with the imposed and accumulated penalty points among KOSPI-listed companies. This may indicate that if foreign investors, albeit their high equity ownership, have a short-term investment propensity, they fail to play a proper monitoring role (Kim \& Kwak, 2013), and therefore cannot effectively control the quality of disclosed information provided by the management. Foreign equity ownership was found to have failed to properly monitor and control unfaithful disclosure in the KOSDAQ market. According to Financial Supervisory Service, the percentage of foreign equity ownership was $32 \%$ in KOSPI and 17\% in KOSDAQ as of 2007, before the global credit crisis, showing foreign investors' preference for KOSPI companies. Among KOSDAQ companies, when other ownership-related variables are factored in, foreign ownership showed a negative effect on corporate values (Kim, 2010). Third, there was a significant positive association between the percentage of managerial ownership and UDC designation in the KOSDAQ market. The higher the managerial ownership, the less agency problem there is between shareholders and the management (Jensen \& Meckling, 1976), which reduces the need for supervising the management, pressure for disclosure and therefore the level of disclosure (Mak, 1991), and its quality. This is in line with the result of research by Sepasi, Kazempour and Mansourlakoraj (2016), which concluded there was significant negative correlation between the managerial ownership percentage and disclosure quality. On the other hand, there was a significant negative correlation between the managerial ownership percentage and the imposed and accumulated penalty points in the KOSDAQ market. This illustrates the fact that even though the higher managerial ownership decreases the agency problem and the level and the quality of disclosures, however, the lowered disclosure level and the quality of disclosure are not serious enough to receive the UDC penalty points of designating as issues for administration and delisting.

This paper contributes to earlier literature in the following ways: first, we propose the influence of corporate governance through empirical study of relationships between corporate governance and designation and imposition penalty scores on UDC in Korea's stock market. Second, even though some already have explored the effect of corporate governance on corporate disclosures (Hope \& Thomas, 2008; Lee \& Sohn, 2005; Lee et al. 2012; Oh \& Shin, 2016) and aspects of unfaithful disclosure corporations (Sohn, Chae \& Oh, 2012; Lee, Park \& Lee, 2014) but we investigated a more detailed look by using unique unfaithful disclosure corporation data in Korea, i.e., designation of UDC and imposition of penalty points on UDC.

The rest of this paper is organized as follows. Section II provides review of previous literature and hypotheses used in the paper. Section III discusses analysis methodology, and Section IV describes the result of empirical analysis and its interpretation. Finally, Section V concludes with implications of the analysis.

\footnotetext{
${ }^{3}$ The ratio of outside directors with direct interests was $19.97 \%$ in 2006 and $18.95 \%$ in 2007, and that of such directors with both direct interests and school ties was $37.50 \%$ in 2006 and $35.44 \%$ in 2007, indicating little improvement in outside directors' independence. In fact, many appointed outside directors are not independent from controlling shareholders and the management, therefore not expected to check and balance them. (Economic Reform Report 2007-6, Center for Good Corporate Governance)
} 


\section{LITERATURE REVIEW AND HYPOTHESES DEVELOPMENT}

\subsection{Unfaithful Disclosure Corporations}

Previous studies on unfaithful disclosure system have mainly explored how disclosure quality degradation caused by UDC designation impacts a company's stakeholders and its reputation in the capital market. Lee, Chun and Park (2008) investigated the impact of disclosure quality degradation caused by UDC designation on the cost of debt based on a sample of UDCs in the KOSPI and KOSDAQ market from 1999 to 2005. This empirical study found that UDCs had to bear a relatively higher cost of debt compared to non-UDCs. This shows how creditors view UDCs. Lee et al. (2012) analyzed whether auditors put in additional audit hours for companies designated as UDC and as a result charge additional audit fees.

The result shows that auditors of companies listed in the KOSPI market recognize the designation as UDC as an audit risk and charge additional fee by putting in extra audit hours. Sohn et al. (2012) verified if UDC designation and the penalty point system impact external auditors' declaration of review and audit opinion of the Internal Accounting Control System. The result shows that companies designated as a UDC or with high accumulated penalty points is more likely to receive a review/audit opinion of the Internal Accounting Control System that is other than unqualified. Lee et al. (2014) examined how the capital market responds to companies designated as UDC and their penalty points. The study found that the stocks' rate of return dropped on the first trading day after the companies' UDC designation, with a statistically significant negative excess earning rate. It also revealed that the higher the accumulated penalty points, the more negatively the capital market responds to UDCs.

Previous studies have so far been aimed at inspecting the effect of unfaithful disclosure in the capital market, whereas this study focuses on corporate governance as a factor affecting such practices, and the correlation between these two. Since unfaithful disclosure is highly likely to be intended by the management (Sohn, 2001), companies with excellent corporate governance, a system designed to monitor and control the management's opportunistic behavior, are expected to be less inclined to disclose unfaithfully.

\subsection{Corporate Governance and Disclosures}

Corporate Governance is a system which mediates the interests of shareholders, BOD, the management and other main stakeholders, and monitors and controls the decision-making process to maximize the corporate values. Among many theories of corporate governance, the main theory related to the study of accounting is the agency theory (Jensen \& Meckling, 1976; Fama \& Jensen, 1983). When ownership and control are separated, the management is often tempted to opt for a decision which would maximize their personal benefit, instead of corporate values. Therefore, an effective control mechanism becomes necessary to monitor such decisions. Excellent corporate governance is a mechanism of eliminating or alleviating agency problems, monitoring and controlling the management's behavior, thereby protecting information users who have relatively less information on the company's management. Corporate disclosure acts to ease the information asymmetry between companies and investors (Diamond \& Verrecchia, 1991), enabling efficient distribution of resources. The management is sometimes motivated to volunteer to disclose reliable information, but at the same time tempted to hide or intentionally distort information to maximize their personal benefits. Therefore, excellent corporate governance may be expected to properly monitor the management's opportunistic practices and provide the market with timely and reliable information.

A number of studies have been conducted on how corporate governance impacts the company's overall policies and level of disclosure. Hope and Thomas (2008) suggested that if the manager dominates the governance with his/her solid position, the company shows a lower level of disclosure. If a mechanism designed to monitor and check the management fails, it exacerbates the agency problem and the management may make a decision against the shareholders' interests. Lee and Sohn (2005) verified if corporate governance impacts the level of disclosure, measured by the number of disclosures. The result indicated that the level of BOD independence, percentage of foreign and institutional investors' equity ownership were proportionate to the level of disclosure. Also, companies with an audit committee had a higher level of disclosure than their counterparts without audit committees, and companies with lower managerial equity ownership had a higher level of disclosure. Lee et al. (2012) inspected the correlation between corporate governance measured by the BOD characteristics and the frequency of disclosures through Fair Disclosure. 
It concluded that the more expertise and independence the BOD has, the more frequent the company discloses information. Oh and Shin (2016) probed into the impact of corporate governance on voluntary disclosure and information asymmetry after the K-IFRS introduction. This empirical analysis found that companies which volunteered to disclose information showed higher information asymmetry, and corporate governance works to alleviate the adverse effects of voluntary disclosure.

Meanwhile, there is little study on the impact of corporate governance on unfaithful disclosure. Therefore, this study will focus on the role of corporate governance as a factor impacting UDC designation and penalty points, which are direct measures of quality of disclosed information provided by the management.

\subsection{Hypotheses Development}

The responsibility of BOD is to supervise the management, to take part in critical decision-making process and to provide advisory input (Fama \& Jensen, 1983). Forker (1992) noted that inclusion of outside director on the board enhances independence, and companies are more likely to comply with the disclosure obligation and provide higherquality financial information. Other studies suggested that independent BOD tend to exercise more supervision on the management; this, in turn, limits the possibility of accounting fraud, reduces the likelihood of correcting past financial statements and increases the frequency of disclosure. Chen and Jaggi (2000), Eng and Mak (2003) and Ajinkya, Bhojraj, and Sengupta (2005) suggested companies with a greater proportion of outside directors are more likely to issue accurate management forecast, arguing that a lower proportion of outside directors or lower institutional ownership leads to less frequent forecasts. Lee and Sohn (2005) found that a lower proportion of outside directors is associated with decreased accuracy of disclosure. On the contrary, some studies showed independent BOD may not play an effective role of management supervision. Kim (2006) showed no relation between the proportion of outside directors and firm value, and Lee, Kim and Jung (2010) reported a significant positive relation between the proportion of outside directors and asset misappropriation. While a BOD is believed to be a critical mechanism to supervise the management and resolve the agency problem between shareholders and managers, there are conflicting results whether independent BOD affects the role of supervision in a positive way. It needs to be seen whether independent BOD would prevent managers' opportunistic behavior and make the managers less motivated to distort information, resulting in less likelihood of UDC designation /penalty points. Interestingly, outside directors in US companies are generally appointed based on their competence and roles in the organization, whereas the appointment of outside directors in the Korean companies is mostly a regulatory compliance, i.e., companies shall have a certain minimum of outside directors depending on their total asset size. In this regard, findings from the US analysis may not hold true for Korean companies. Thus, in this study, WE used the following null hypotheses, Hypotheses 1-1 and 1-2, to analyze how the independent BOD, measured by the proportion of outside directors, influences UDC designation/penalty points:

Hypothesis 1-1: There is no significant relationship between the independent BOD (measured by the proportion of outside directors) and UDC designation.

Hypothesis 1-2: There is no significant relationship between the independent BOD (measured by the proportion of outside directors) and penalty points.

Prior research reported that foreign investors are familiar with advanced investment practice and play an effective role of management supervision, so companies invested by foreigners tend to disclose accurate earnings information; and the existence of foreign investors also helps companies increase financing activities such as distribution of dividends and investment, resulting in enhanced corporate value (Rho, Bae, \& Cheon, 2003; Kim \& Kim, 2007; Chung, Ho \& Kim 2004). Sachs and Warner (1995) also found that foreign investors are proactive in supervising the management because supervision can be a means to reduce information costs arising from information asymmetry between domestic investors and foreign investors. In other words, foreign investors are known to reduce agency costs thanks to their advanced investment knowledge and proactive supervision.

In contrast, some studies discuss that foreign investors bring more harm than good to companies. In fact, some companies have experienced adverse effects from foreign investment; companies cannot create sustainable value if 
foreign investors ask for higher dividends by taking advantage of their right as a large shareholder, and focus on shortterm profit harvesting by threatening or controlling the management. (Park \& Lee, 2006; Kim \& Cheon, 2004).

It may be predicted that the higher the percentage of foreign ownership is, the less likely a company would be designated as a UDC; the management and the decision-making process would be effectively supervised and controlled by foreign investors, leading to more accurate information disclosure. On the contrary, some might argue that foreign investors are mostly interested in high dividends and short-term profit, so they would not play an effective monitoring role on the management and this affects a company being designated as UDC and receiving penalties. With such conflicting views on foreign investors' influence on disclosure, WE used the following null hypotheses, Hypotheses 2-1 and 2-2, to analyze how corporate governance, measured by the percentage of foreign equity ownership, influences UDC designation/penalty points:

Hypothesis 2-1: There is no significant relationship between the percentage of foreign equity ownership and UDC designation.

Hypothesis 2-2: There is no significant relationship between the percentage of foreign equity ownership and the penalty points.

Generally, it is known that corporate ownership structure has a huge influence on the level of disclosure. Prior studies reported that there is a significant negative correlation between managerial ownership and the level of disclosure (Mak, 1991; Eng \& Mak, 2003). Increased managerial ownership aligns the interest between shareholders and managers, reducing the agency problem (Jensen \& Meckling, 1976); under this circumstance, no one forces companies to issue disclosure, which ends up compromising the level of disclosure. Sepasi et al. (2016) discovered that managerial ownership has a significant negative effect on disclosure quality. According to Morck, Shleifer, and Vishny (1988), if managers have a certain percentage of corporate ownership, they are more likely to pursue perquisite-taking and non-value-maximizing behavior. The higher managerial ownership is, the more likelihood that managers are motivated to issue distorted information to maximize their personal benefits. Thus, we can expect that the percentage of managerial equity ownership and UDC designation/penalty points would be positively related. On the other hand, a higher managerial ownership reduces the agency problem and managers are more motivated to publicly disseminate private information to the market (Nagar, Nanda \& Wysocki 2003). In this case, the percentage of managerial equity ownership and UDC designation/penalty points would be positively related. Thus, WE used the following null hypotheses, Hypotheses 3-1 and 3-2, to analyze how the percentage of managerial equity ownership influences UDC designation and penalty points:

Hypothesis 3-1: There is no significant relationship between the percentage of managerial equity ownership and UDC designation.

Hypothesis 3-2: There is no significant relationship between the percentage of managerial equity ownership and penalty points.

\section{RESEARCH DESIGN}

\subsection{Methodology and Variable Definitions}

We built the following formula to empirically analyze how corporate governance influences UDC designation and the penalty points, using the proportion of outside directors, the percentage of foreign ownership and that of managerial ownership as proxies.

$$
\begin{aligned}
& \text { UNFAITHFUL DISCLOSURE }=\beta_{0}+\beta_{1} \text { GOVERNANCE }+\beta_{2} \text { SIZE }+\beta_{3} L E V+\beta_{4} R O A+\beta_{5} L I S T \\
& +\beta_{6} \text { OIVOL }+\beta_{7} \text { GROW }+\beta_{8} Z S C O R E+\beta_{9} \text { BIG }+\beta_{10} M K T+Y E A R D U M M Y+D U S T R Y \text { DUMMY }
\end{aligned}
$$


Where

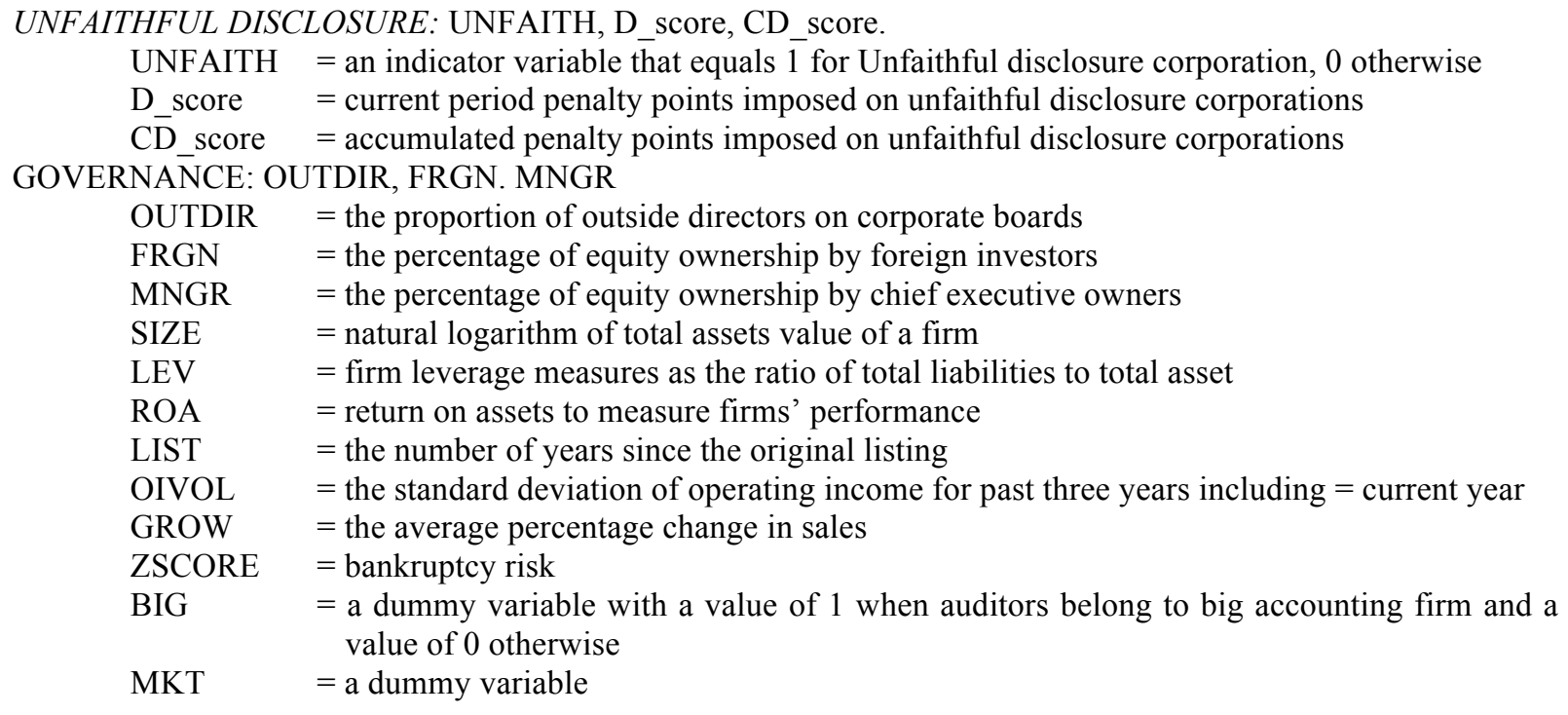

with a value of 1 when a firm is listed in KOSPI and a value of 0 otherwise

First, UDC designation and imposed/accumulated penalty points are applied to the dependent variable UNFAITHFUL DISCLOSURE. The independent variable of interest $\left(\beta_{1}\right)$ uses proportion of outside directors (OUTDIR) for verification of hypothesis 1 , percentage of foreign equity ownership (FRGN) for hypothesis 2 , and percentage of managerial equity ownership(MNGR) for hypothesis 3. In addition, following variables have been controlled as they are believed to affect UDC designation and penalty points. Firms with bigger SIZE are expected to show higher level of disclosure compared to their smaller counterparts (Foster, 1986). Firms with higher LEV are expected to disclose more diligently to minimize their legal responsibilities (Bradbury, 1992). Firms with higher ROA are expected to be less motivated to disclose unfaithfully as they are more likely to volunteer to disclose. LIST has been added to control firms delisted between the date of UDC designation and 2015. In addition to these variables, firms with highly volatile or rapidly growing operating profit or high risk of bankruptcy will have to disclose more contents to investors, which is deemed to have an influence on unfaithful disclosure. Therefore, OIVOL, GROW and ZSCORE are controlled. BIG are controlled to prevent the auditor's affiliation to BIG accounting firms from influencing disclosure quality.

\subsection{Sampling}

For this study, we collected data such as UDC designation, imposed penalty points and accumulated penalty points from the Korea Exchange's electronic disclosure system (kind.krx.co.kr). The information on UDC designation is only available from 2000 , therefore our empirical analysis related to the designation is conducted for companies listed from 2000 to 2015. Meanwhile, since the penalty point and its accumulation were introduced in 2004, the empirical analysis about these variables is conducted for data from 2004 to 2015. Proportion of outside directors, percentage of foreign and managerial equity ownership used as proxy for corporate governance, and financial data for calculation of financial/accounting information used as other controlled variables are from non-financial firms closing in December on Korea Listed Companies Association's TS2000 database. The total samples from 2000 to 2015 used for empirical analysis of this study is 22,654 firm-years, and samples from 2004, used for empirical analysis using imposed and accumulated penalty points consist of 18,185 firm-years. 


\section{RESULTS}

\subsection{Descriptive Statistics and Correlations}

Table 1 provides basics statistics of main variables. In this study, values smaller (bigger) than $1 \%(99 \%)$ of the distribution of each variable were replaced with $1 \%(99 \%)$ values, in order to reduce the impact of outliers. The average of UNFAITH variable, which refers to whether a firm is designated as a UDC, is 0.045 , indicating that $4.5 \%$ of all samples, or 1,019 firm-years, are designated as UDCs. D_SCORE and CD_SCORE basic statistic data are collected from 820 companies, as these scores are imposed on companies designated as UDC since 2004. Though not provided on Table 1, penalty score imposed within a period is distributed from 0 to 21 , and D-SCORE has an average of 5.029 and a median of 4 . Accumulated penalty score is distributed from 0 to 40, and CD_SCORE has an average of 7.023 and a median of 5 . The average proportion of outside directors is 0.135 , indicating that outside directors take up $13.5 \%$ of all directors. The average FRGN is 6 , showing that foreign investors own an average of $6 \%$ of firms' entire equity ownership. The average percentage of managerial equity ownership was $8.4 \%$.

Table 1. Descriptive Statistics of the Main Variables

\begin{tabular}{|c|c|c|c|c|c|c|c|c|c|}
\hline Variables & Mean & Std. Dev. & $5 \%$ & $10 \%$ & $25 \%$ & MED. & $75 \%$ & $90 \%$ & $95 \%$ \\
\hline UNFAITH & 0.045 & 0.207 & 0 & 0 & 0 & 0 & 0 & 0 & 0 \\
\hline D_SCORE & 5.029 & 5.270 & 0 & 0 & 2 & 4 & 7.5 & 10 & 11 \\
\hline CD_SCORE & 7.023 & 8.329 & 0 & 0 & 2 & 5 & 10 & 16 & 21 \\
\hline OUTDIR & 0.135 & 0.119 & 0 & 0 & 0 & 0.125 & 0.200 & 0.286 & 0.333 \\
\hline$F R G N$ & 6.001 & 11.047 & 0 & 0 & 0.060 & 0.880 & 6.080 & 20.430 & 32.060 \\
\hline MNGR & 0.084 & 0.124 & 0 & 0 & 0 & 0.015 & 0.134 & 0.261 & 0.351 \\
\hline$S I Z E$ & 18.593 & 1.436 & 16.674 & 17.006 & 17.609 & 18.344 & 19.306 & 20.500 & 21.511 \\
\hline$L E V$ & 0.429 & 0.229 & 0.096 & 0.143 & 0.254 & 0.419 & 0.576 & 0.703 & 0.800 \\
\hline $\boldsymbol{R O A}$ & -0.024 & 0.223 & -0.379 & -0.188 & -0.020 & 0.027 & 0.067 & 0.111 & 0.143 \\
\hline LIST & 19.563 & 10.375 & 6.000 & 9.000 & 13.000 & 16.000 & 25.00 & 39.000 & 41.000 \\
\hline OIVOL & 0.047 & 0.051 & 0.003 & 0.006 & 0.015 & 0.031 & 0.058 & 0.103 & 0.149 \\
\hline GROWTH & -0.052 & 0.400 & -1.316 & -0.408 & -0.064 & 0.037 & 0.132 & 0.252 & 0.349 \\
\hline Z-Score & -0.862 & 5.737 & -4.969 & -4.339 & -3.405 & -2.375 & -0.745 & 3.423 & 8.499 \\
\hline$B I G$ & 0.500 & 0.500 & 0 & 0 & 0 & 1 & 1 & 1 & 1 \\
\hline
\end{tabular}

Note: This table reports descriptive statistics of the mean, median, and distributions of main variables used in this paper. All variables are winsorized at top and bottom one-percentile of the pooled data.

Table 2 provides the Pearson correlation coefficients between different variables. OUTDIR has a significant positive association with UNFAITH, D_score and CD_score, implying that the higher the proportion of outside directors, the more likely the firm is to be designated as UDC or get penalty points. On the other hand, FRGN and MNG have a significant negative association with UNFAITH, D_score and CD_score, implying that higher percentage of foreign or managerial equity ownership leads to relatively lower possibilities of UDC designation and penalty points. However, since UNFAITH, D_score and CD_score are reported to have a significant correlation with other controlled variables set in the research model, it would be difficult to draw a definitive conclusion on the correlation between corporate governance and UDC designation/penalty points, simply based on correlation coefficients between main variables on Table 2. Therefore, the final empirical analysis result is reported in the next section, based on the multiple regression analysis result considering all variables included in the research model formula. 
Table 2. Pearson Correlation Between Variables Analyzed

\begin{tabular}{|c|c|c|c|c|c|c|c|}
\hline & UNFAITH & D_SCORE & CD_SCORE & OUTDIR & FRGN & MNGR & SIZE \\
\hline D_SCORE & $0.664^{* * *}$ & & & & & & \\
\hline CD_SCORE & $0.619^{* * *}$ & $0.891^{* * *}$ & & & & & \\
\hline OUT'DIR & $0.034^{* * *}$ & $0.022^{* * *}$ & $0.028^{* * *}$ & & & & \\
\hline FRGN & $-0.060^{* * *}$ & $-0.050^{* * *}$ & $-0.050^{* * *}$ & $0.028^{* * *}$ & & & \\
\hline MNGR & $-0.045^{* * *}$ & $-0.039^{* * *}$ & $-0.038^{* * *}$ & $-0.027^{* * *}$ & $-0.082^{* * *}$ & & \\
\hline SIZE & $-0.114^{* * *}$ & $-0.116^{* * *}$ & $-0.120^{* * *}$ & $0.094^{* * *}$ & $0.460^{* * *}$ & $-0.109^{* * *}$ & \\
\hline LEV & $0.152^{* * *}$ & $0.151^{* * *}$ & $0.148^{* * *}$ & -0.005 & $-0.096^{* * *}$ & $-0.161^{* * *}$ & $0.123^{* * *}$ \\
\hline ROA & $-0.310^{* * *}$ & $-0.315^{* * *}$ & $-0.314^{* * *}$ & $-0.037^{* * *}$ & $0.154^{* * *}$ & $0.085^{* * *}$ & $0.283^{* * *}$ \\
\hline LIST & -0.010 & $-0.015^{* *}$ & $-0.014^{* *}$ & $0.069^{* * *}$ & $0.139^{* * *}$ & $-0.140^{* * *}$ & $0.361^{* * *}$ \\
\hline OIVOL & $0.206^{* * *}$ & $0.212^{* * *}$ & $0.220^{* * *}$ & $0.023^{* * *}$ & $-0.105^{* * *}$ & $-0.037^{* * *}$ & $-0.314^{* * *}$ \\
\hline GROWTH & $-0.043^{* * *}$ & $-0.066^{* * *}$ & $-0.066^{* * *}$ & $0.065^{* * *}$ & $0.089^{* * *}$ & $0.014^{* *}$ & $0.192^{* * *}$ \\
\hline Z-Score & $0.266^{* * *}$ & $0.275^{* * *}$ & $0.275^{* * *}$ & $0.019^{* * *}$ & $-0.133^{* * *}$ & $-0.042^{* * *}$ & $-0.275^{* * *}$ \\
\hline BIG & $-0.066^{* * *}$ & $-0.051^{* * *}$ & $-0.053^{* * *}$ & $0.019^{* * *}$ & $0.225^{* * *}$ & $-0.070^{* * *}$ & $0.348^{* * *}$ \\
\hline
\end{tabular}

(Table 2 continued)

\begin{tabular}{|c|c|c|c|c|c|c|}
\hline & LEV & ROA & LIST & OIVOL & GROWTH & Z-Score \\
\hline ROA & $-0.389^{* * *}$ & & & & & \\
\hline LIST & $0.149^{* * *}$ & $0.026^{* * *}$ & & & & \\
\hline OIVOL & $0.160^{* * *}$ & $-0.495^{* * *}$ & $-0.086^{* * *}$ & & & \\
\hline GROWTH & $-0.040^{* * *}$ & $0.263^{* * *}$ & $0.145^{* * *}$ & 0.006 & & \\
\hline Z-Score & $0.283^{* * *}$ & $-0.864^{* * *}$ & $-0.052^{* * *}$ & $0.433^{* * *}$ & $-0.264^{* * *}$ & \\
\hline BIG & $-0.015^{* *}$ & $0.120^{* * *}$ & $0.047^{* * *}$ & $-0.097^{* * *}$ & -0.009 & $-0.114^{* * *}$ \\
\hline
\end{tabular}

Note: This table presents Pearson correlation between the corporate governance variables, i.e. percentage of outside directors, the percentage of foreign ownership and that of managerial ownership, designation of unfaithful disclosure corporation, imposition of penalty points on unfaithful disclosure corporation designation, and other control variables. ${ }^{* *},{ }^{* *}$ and $*$ denote the significance level (two-tailed) at $1 \%, 5 \%$ and $10 \%$ or less, respectively.

\subsection{Regression Analysis Results}

Table 3 shows the logistic regression analysis result on whether UDC designation is impacted by proxy variables of corporate governance, namely proportion of outside directors and percentage of foreign/managerial equity ownership. Panel A is the result of analysis of all listed companies, and Panel B and C are results of empirical analysis of companies on KOSPI and KOSDAQ, respectively. In terms of proportion of outside directors, OUTDIR variable had a negative sign at $1 \%$ level regardless of markets, implying that higher proportion of outside directors leads to lower probabilities of UDC designation. This implies that outside director system checks and balances the management, thereby effectively playing the role of reducing errors in timeliness, accuracy and reliability of disclosed information. On the other hand, FRGN showed a significant positive sign at 10\% level among samples in the overall market and KOSDAQ market, indicating that higher foreign ownership leads to higher probabilities of UDC designation. Also, Managerial ownership also showed a significant positive sign at $1 \%$ level among samples in the overall market, mainly attributable to KOSDAQ-listed companies. That is, for companies listed on KOSDAQ, higher managerial ownership means higher probabilities of UDC designation. The higher the managerial ownership, the less agency problem there is between shareholders and the management (Jensen \& Mecking, 1976), which reduces the need for supervising the management, pressure for disclosure and therefore the level of disclosure (Mak, 1991), and its quality. This is in line with the result of research by Sepasi et al. (2016), which concluded there was significant negative correlation between the managerial ownership percentage and disclosure quality. 
Table 3. Results of Multivariate Regression Analysis (Designated as Unfaithful Disclosure Corporation

\begin{tabular}{|c|c|c|c|c|c|c|c|c|}
\hline \multirow{2}{*}{\multicolumn{9}{|c|}{$\begin{array}{l}\text { UNFAITH }=\beta_{0}+\beta_{1} \text { GOVERNANCL } \\
\beta_{8} \text { ZSCORE }+\beta_{9} B I G+Y E A R \text { DUMI } \\
\text { Panel A: KOSPI and KOSDAQ }\end{array}$}} \\
\hline & & & & & & & & \\
\hline Variable & Estimate & $\begin{array}{c}\text { Wald } \\
\chi 2 \text { value }\end{array}$ & Estimate & $\begin{array}{c}\text { Wald } \\
\chi 2 \text { value }\end{array}$ & Estimate & $\begin{array}{c}\text { Wald } \\
\chi 2 \text { value }\end{array}$ & Estimate & $\begin{array}{c}\text { Wald } \\
\chi 2 \text { value }\end{array}$ \\
\hline Intercept & 17.372 & 0.00 & 17.077 & 0.00 & 17.527 & & 17.093 & 0.00 \\
\hline OUTDIR & $-0.978^{* * *}$ & 11.66 & $-1.010^{* * *}$ & 12.46 & & & & \\
\hline FRGN & $0.009^{*}$ & 2.98 & & & 0.008 & 2.58 & & \\
\hline MNGR & $1.395^{* * *}$ & 17.19 & & & & & $1.410^{* * *}$ & 17.48 \\
\hline SIZE & $0.218^{* * *}$ & 27.20 & $0.239^{* * *}$ & 36.09 & $0.215^{* * *}$ & 25.72 & $0.241^{* * *}$ & 37.06 \\
\hline LEV & $-1.226^{* * *}$ & 63.21 & $-1.295^{* * *}$ & 71.80 & $-1.245^{* * *}$ & 65.18 & $-1.248^{* * *}$ & 66.50 \\
\hline ROA & $3.087^{* * *}$ & 55.25 & $3.179^{* * *}$ & 57.60 & $3.231^{* * *}$ & 59.13 & $3.183^{* * *}$ & 57.00 \\
\hline LIST & $-0.010^{* *}$ & 4.97 & $-0.012^{* * *}$ & 7.24 & $-0.013^{* * *}$ & 9.34 & $-0.012^{* * *}$ & 7.08 \\
\hline OIVOL & $-3.122^{* * *}$ & 28.75 & $-3.194^{* * *}$ & 30.06 & $-3.251^{* * *}$ & 31.11 & $-3.130^{* * *}$ & 28.85 \\
\hline GROW & $-0.928^{* * *}$ & 65.35 & $-0.931^{* * *}$ & 65.55 & $-0.932^{* * *}$ & 66.00 & $-0.939^{* * *}$ & 67.09 \\
\hline Z-Score & $0.041^{* *}$ & 5.23 & $0.044^{* *}$ & 6.09 & $0.045^{* *}$ & 6.36 & $0.045^{* *}$ & 6.14 \\
\hline BIG & $0.315^{* * *}$ & 16.53 & $0.309^{* * *}$ & 15.93 & $0.313^{* * *}$ & 16.46 & $0.333^{* * *}$ & 18.46 \\
\hline $\begin{array}{l}\text { Industry \& } \\
\text { Year Dummies }\end{array}$ & \multicolumn{8}{|c|}{ Fixed } \\
\hline $\begin{array}{l}\text { Likelihood } \\
\text { Ratio } \chi^{2}\end{array}$ & \multicolumn{2}{|c|}{$1450.0904^{* * *}$} & \multicolumn{2}{|c|}{$1428.0090^{* * *}$} & \multicolumn{2}{|c|}{$1418.3484^{* * *}$} & \multicolumn{2}{|c|}{$1435.2129^{* * *}$} \\
\hline \# of Samples & \multicolumn{2}{|c|}{22,654} & \multicolumn{2}{|c|}{22,654} & \multicolumn{2}{|c|}{22,654} & \multicolumn{2}{|c|}{22,654} \\
\hline \multicolumn{9}{|l|}{ Panel B: KOSPI } \\
\hline Variable & Estimate & $\begin{array}{c}\text { Wald } \\
\chi^{2} \text { value }\end{array}$ & Estimate & $\begin{array}{c}\text { Wald } \\
\chi^{2 \text { value }}\end{array}$ & Estimate & $\begin{array}{c}\text { Wald } \\
\chi^{2 \text { value }}\end{array}$ & Estimate & $\begin{array}{c}\text { Wald } \\
\chi 2 \text { value }\end{array}$ \\
\hline Intercept & 16.547 & 0.00 & 16.220 & 0.00 & 16.329 & 0.00 & 16.036 & 0.00 \\
\hline OUTDIR & $-1.142^{* *}$ & 3.51 & $-1.161^{*}$ & 3.63 & & & & \\
\hline FRGN & 0.006 & 0.56 & & & 0.006 & 0.65 & & \\
\hline MNGR & -0.225 & 0.12 & & & & & -0.263 & 0.17 \\
\hline Control Var. & \multicolumn{8}{|c|}{ Controlled } \\
\hline $\begin{array}{l}\text { Industry \& } \\
\text { Year Dummies }\end{array}$ & \multicolumn{8}{|c|}{ Fixed } \\
\hline $\begin{array}{l}\text { Likelihood } \\
\text { Ratio } \chi^{2}\end{array}$ & \multicolumn{2}{|c|}{$389.8816^{* * *}$} & \multicolumn{2}{|c|}{$388.0499^{* * *}$} & \multicolumn{2}{|c|}{$385.0521^{* * *}$} & \multicolumn{2}{|c|}{$383.3054^{* * *}$} \\
\hline \# of Samples & & & & & & & & \\
\hline
\end{tabular}

\begin{tabular}{|c|c|c|c|c|c|c|c|c|}
\hline \multicolumn{9}{|c|}{ Panel C: KOSDAQ } \\
\hline Variable & Estimate & $\begin{array}{c}\text { Wald } \\
\chi^{2 \text { value }}\end{array}$ & Estimate & $\begin{array}{c}\text { Wald } \\
\chi^{2 \text { value }}\end{array}$ & Estimate & $\begin{array}{c}\text { Wald } \\
\chi^{2 \text { value }}\end{array}$ & Estimate & $\begin{array}{c}\text { Wald } \\
\chi^{2} \text { value }\end{array}$ \\
\hline Intercept & -2.266 & 2.26 & $-2.689^{* *}$ & 3.23 & $-2.546^{*}$ & 2.83 & $-2.781^{*}$ & 3.52 \\
\hline OUTDIR & $-1.361^{* * *}$ & 11.68 & $-1.394^{* * *}$ & 12.32 & & & & \\
\hline FRGN & $0.015^{*}$ & 2.83 & & & 0.012 & 2.01 & & \\
\hline MNGR & $2.028^{* * *}$ & 18.97 & & & & & $2.041^{* * *}$ & 19.18 \\
\hline Control Var. & \multicolumn{8}{|c|}{ Controlled } \\
\hline $\begin{array}{l}\text { Industry \& } \\
\text { Year Dummies }\end{array}$ & \multicolumn{8}{|c|}{ Fixed } \\
\hline $\begin{array}{l}\text { Likelihood } \\
\text { Ratio } \chi^{2}\end{array}$ & \multicolumn{2}{|c|}{$1175.4399^{* * *}$} & \multicolumn{2}{|c|}{$1147.9485^{* * *}$} & \multicolumn{2}{|c|}{$1135.0319^{* * *}$} & \multicolumn{2}{|c|}{$1159.9558^{* * *}$} \\
\hline \# of Samples & \multicolumn{8}{|c|}{13,308} \\
\hline
\end{tabular}

Note: This table presents the coefficient estimators of logit regression for corporate governance (OUTDIR, FRGN, MNGR) on unfaithful disclosure corporation designation $(U N F A I T H) .{ }^{* * *},{ }^{* *}$ and $*$ denote the significance level (two-tailed) at $1 \%, 5 \%$ and $10 \%$ or less, respectively.

Table 4 shows the multiple regression analysis result on whether penalty points for unfaithful disclosure is impacted by proxy variables of corporate governance, namely proportion of outside directors and percentage of foreign/managerial equity ownership. Similarly, Table 3, Panel A is the result of analysis of all listed companies, and 
Panel B and C are results of empirical analysis of companies on KOSPI and KOSDAQ, respectively. In terms of proportion of outside directors, OUTDIR variable had a significant positive sign at $5 \%$ level in the overall market, implying that higher proportion of outside directors leads to higher penalty points for unfaithful disclosure. This trend is not found among the KOSPI samples on Panel B, but OUTDIR showed a significant positive sign at $1 \%$ level on Panel C, meaning this correlation is confined to KOSDAQ companies. FRGN showed a significant positive sign at $5 \%(10 \%)$ level in the overall (KOSPI) market, showing that for KOSPI companies, higher percentage of foreign ownership leads to higher penalty points for unfaithful disclosure. This may indicate that if foreign investors, albeit their high equity ownership, have a short-term investment propensity, they fail to play a proper monitoring role (Kim \& Kwak, 2013), and therefore cannot effectively control the quality of disclosed information provided by the management. Meanwhile, managerial equity ownership showed a significant negative sign at $5 \%(1 \%)$ level in the overall (KOSDAQ) market, indicating that for KOSDAQ companies, higher managerial ownership leads to lower penalty points for unfaithful disclosure.

Table 4. Results of Multivariate Regression Analysis (D Score)

\begin{tabular}{|c|c|c|c|c|c|c|c|c|}
\hline \multirow{2}{*}{\multicolumn{9}{|c|}{$\begin{array}{l}D_{-} \text {Score }=\beta_{0}+\beta_{1} \text { GOVERNANCE }(C \\
\beta_{8} \text { ZSCORE }+\beta_{9} \text { BIG }+ \text { YEAR DUMM } \\
\text { Panel A: KOSPI and KOSDAQ }\end{array}$}} \\
\hline & & & & & & & & \\
\hline Variable & Estimate & t-value & Estimate & t-value & Estimate & t-value & Estimate & t-value \\
\hline Intercept & 0.675 & 0.47 & 0.523 & 0.36 & 0.624 & 0.43 & 0.524 & 0.36 \\
\hline OUTDIR & $0.177^{* *}$ & 2.20 & $0.177^{* *}$ & 2.20 & & & & \\
\hline$F R G N$ & $0.002^{* *}$ & 2.26 & & & $0.002^{* *}$ & 2.33 & & \\
\hline$M N G R$ & $-0.170^{* *}$ & -2.17 & & & & & $-0.180^{* *}$ & -2.31 \\
\hline SIZE & $-0.041^{* * *}$ & -4.18 & $-0.030^{* * *}$ & -3.39 & $-0.038^{* * *}$ & -3.97 & $-0.030^{* * *}$ & -3.46 \\
\hline$L E V$ & $0.318^{* * *}$ & 6.53 & $0.308^{* * *}$ & 6.44 & $0.325^{* * *}$ & 6.69 & $0.296^{* * *}$ & 6.18 \\
\hline$R O A$ & $-1.549^{* * *}$ & -16.64 & $-1.557^{* * *}$ & -16.74 & $-1.566^{* * *}$ & -16.84 & $-1.556^{* * *}$ & -16.73 \\
\hline LIST & 0.000 & 0.21 & 0.000 & 0.31 & 0.001 & 0.55 & 0.000 & 0.30 \\
\hline OIVOL & $1.763^{* * *}$ & 8.00 & $1.805^{* * *}$ & 8.21 & $1.787^{* * *}$ & 8.11 & $1.802^{* * *}$ & 8.19 \\
\hline GROW & 0.004 & 0.14 & 0.002 & 0.09 & 0.004 & 0.18 & 0.005 & 0.21 \\
\hline Z-Score & $0.006^{*}$ & 1.75 & $0.006^{*}$ & 1.73 & $0.005^{*}$ & 1.65 & $0.006^{*}$ & 1.75 \\
\hline$B I G$ & -0.029 & -1.40 & -0.024 & -1.17 & -0.028 & -1.36 & -0.028 & -1.35 \\
\hline $\begin{array}{l}\text { Industry and } \\
\text { Year }\end{array}$ & \multicolumn{8}{|c|}{ Fixed } \\
\hline Adj. $\mathrm{R}$ & \multicolumn{2}{|c|}{$10.88 \%$} & & & \multirow{2}{*}{\multicolumn{2}{|c|}{$10.85 \%$}} & \multicolumn{2}{|c|}{$10.85 \%$} \\
\hline \# of Samples & \multicolumn{6}{|c|}{18,185} & & \\
\hline
\end{tabular}

\begin{tabular}{|c|c|c|c|c|c|c|c|c|}
\hline \multicolumn{9}{|c|}{ Panel B: KOSPI } \\
\hline Variable & Estimate & t-value & Estimate & t-value & Estimate & t-value & Estimate & t-value \\
\hline Intercept & 0.605 & 0.38 & 0.477 & 0.30 & 0.655 & 0.41 & 0.439 & 0.28 \\
\hline OUTDIR & 0.037 & 0.22 & 0.035 & 0.21 & & & & \\
\hline$F R G N$ & $0.003^{*}$ & 1.87 & & & $0.003^{*}$ & 1.82 & & \\
\hline$M N G R$ & 0.215 & 1.30 & & & & & 0.205 & 1.25 \\
\hline Control Var. & \multicolumn{8}{|c|}{ Controlled } \\
\hline $\begin{array}{l}\text { Industry and } \\
\text { Year }\end{array}$ & \multicolumn{8}{|c|}{ Fixed } \\
\hline Adj. R & \multicolumn{2}{|c|}{$8.96 \%$} & & & \multirow{2}{*}{\multicolumn{2}{|c|}{$8.97 \%$}} & \multirow{2}{*}{\multicolumn{2}{|c|}{$8.95 \%$}} \\
\hline \# of Samples & & & & & & & & \\
\hline
\end{tabular}

(Table 4 continued on next page) 
(Table 4 continued)

\begin{tabular}{|c|c|c|c|c|c|c|c|c|}
\hline \multicolumn{9}{|c|}{ Panel C: KOSDAQ } \\
\hline Variable & Estimate & t-value & Estimate & t-value & Estimate & t-value & Estimate & t-value \\
\hline Intercept & $0.996^{* *}$ & 2.50 & $0.868^{* *}$ & 2.23 & $0.979^{* *}$ & 2.46 & $0.855^{* *}$ & 2.20 \\
\hline OUTDIR & $0.375^{* * *}$ & 3.15 & $0.387^{* * *}$ & 3.25 & & & & \\
\hline$F R G N$ & 0.002 & 1.35 & & & 0.003 & 1.51 & & \\
\hline$M N G R$ & $-0.267^{* *}$ & -2.50 & & & & & $-0.286^{* * *}$ & -2.68 \\
\hline Control Var. & \multicolumn{8}{|c|}{ Controlled } \\
\hline $\begin{array}{l}\text { Industry and } \\
\text { Year }\end{array}$ & \multicolumn{8}{|c|}{ Fixed } \\
\hline Adj. R & \multicolumn{2}{|c|}{$14.08 \%$} & \multicolumn{2}{|c|}{$14.03 \%$} & \multirow{2}{*}{\multicolumn{2}{|c|}{$13.96 \%$}} & \multicolumn{2}{|c|}{$14 \%$} \\
\hline \# of Samples & \multicolumn{6}{|c|}{10,928} & & \\
\hline
\end{tabular}

Note: This table presents the coefficient estimators of regression for corporate governance (OUTDIR, FRGN, MNGR) on penalty points for unfaithful disclosure $\left(D \_s c o r e\right) . * * *, * *$ and $*$ denote the significance level (two-tailed) at $1 \%, 5 \%$ and $10 \%$ or less, respectively.

Table 5 shows the multiple regression analysis result on whether accumulated penalty points for unfaithful disclosure is impacted by proxy variables of corporate governance, namely proportion of outside directors and percentage of foreign/managerial equity ownership. Similarly to Table 3, Panel A is the result of analysis of all listed companies, and Panel $\mathrm{B}$ and $\mathrm{C}$ are results of empirical analysis of companies on KOSPI and KOSDAQ, respectively. In terms of proportion of outside directors, OUTDIR variable had a significant positive sign at $1 \%$ level in the overall market, implying that higher proportion of outside directors leads to higher accumulated penalty points for unfaithful disclosure. This trend is not found among the KOSPI samples on Panel B, but OUTDIR showed a significant positive sign at $1 \%$ level on Panel $\mathrm{C}$, meaning this correlation is confined to KOSDAQ companies. FRGN showed a significant positive sign at $1 \%(5 \%)$ level in the overall (KOSPI) market, showing that for KOSPI companies, higher percentage of foreign ownership leads to higher accumulated penalty points for unfaithful disclosure. Meanwhile, managerial equity ownership showed a significant negative sign at $5 \%(10 \%)$ level in the overall (KOSDAQ) market, indicating that for KOSDAQ companies, higher managerial ownership leads to lower accumulated penalty points for unfaithful disclosure. This illustrates the fact that even though the higher managerial ownership decrease the agency problem and the level and the quality of disclosures, however, the lowered disclosure level and the quality of disclosure are not serious enough to receive the UDC accumulated penalty points of designating as issues for administration and delisting.

Table 5. Results of Multivariate Regression Analysis (CD Score)

\begin{tabular}{|c|c|c|c|c|c|c|c|c|}
\hline \multicolumn{9}{|c|}{ Panel A: KOSPI and KOSDAQ } \\
\hline Variable & Estimate & t-value & Estimate & t-value & Estimate & t-value & Estimate & t-value \\
\hline Intercept & 1.155 & 0.55 & 0.908 & 0.43 & 1.067 & 0.51 & 0.893 & 0.42 \\
\hline OUTDIR & $0.353^{* * *}$ & 3.00 & $0.352^{* * *}$ & 2.99 & & & & \\
\hline$F R G N$ & $0.004^{* * *}$ & 2.60 & & & $0.004^{* * *}$ & 2.65 & & \\
\hline$M N G R$ & $-0.231^{* *}$ & -2.03 & & & & & $-0.250^{* *}$ & -2.19 \\
\hline SIZE & $-0.072^{* * *}$ & -5.09 & $-0.054^{* * *}$ & -4.25 & $-0.069^{* * *}$ & -4.86 & $-0.055^{* * *}$ & -4.28 \\
\hline$L E V$ & $0.471^{* * *}$ & 6.63 & $0.451^{* * *}$ & 6.47 & $0.479^{* * *}$ & 6.76 & $0.435^{* * *}$ & 6.21 \\
\hline$R O A$ & $-2.150^{* * *}$ & -15.81 & $-2.162^{* * *}$ & -15.91 & $-2.178^{* * *}$ & -16.04 & $-2.165^{* * *}$ & -15.93 \\
\hline LIST & 0.001 & 0.80 & 0.001 & 0.88 & 0.002 & 1.20 & 0.001 & 0.94 \\
\hline OIVOL & $3.119^{* * *}$ & 9.69 & $3.185^{* * *}$ & 9.92 & $3.158^{* * *}$ & 9.82 & $3.188^{* * *}$ & 9.92 \\
\hline GROW & -0.013 & -0.34 & -0.014 & -0.39 & -0.010 & -0.27 & -0.009 & -0.25 \\
\hline Z-Score & $0.009^{*}$ & 1.93 & $0.009^{* *}$ & 1.92 & $0.009^{*}$ & 1.81 & $0.009^{*}$ & 1.92 \\
\hline$B I G$ & -0.037 & -1.24 & -0.030 & -1.00 & -0.037 & -1.23 & -0.036 & -1.20 \\
\hline $\begin{array}{l}\text { Industry and } \\
\text { Year }\end{array}$ & \multicolumn{8}{|c|}{ Fixed } \\
\hline Adj. $\mathrm{R}$ & \multicolumn{2}{|c|}{$10.88 \%$} & \multicolumn{2}{|c|}{$10.85 \%$} & \multirow{2}{*}{\multicolumn{2}{|c|}{$10.85 \%$}} & \multicolumn{2}{|c|}{$10.85 \%$} \\
\hline \# of Samples & \multicolumn{6}{|c|}{18,185} & & \\
\hline
\end{tabular}




\begin{tabular}{|c|c|c|c|c|c|c|c|c|}
\hline \multicolumn{9}{|c|}{ Panel B: KOSPI } \\
\hline Variable & Estimate & t-value & Estimate & t-value & Estimate & t-value & Estimate & t-value \\
\hline Intercept & 1.132 & 0.50 & 0.871 & 0.39 & 1.193 & 0.53 & 0.832 & 0.37 \\
\hline OUTDIR & 0.067 & 0.28 & 0.062 & 0.26 & & & & \\
\hline$F R G N$ & $0.005^{* *}$ & 2.37 & & & $0.005^{* *}$ & 2.33 & & \\
\hline$M N G R$ & 0.245 & 1.05 & & & & & 0.227 & 0.97 \\
\hline Control Var. & \multicolumn{8}{|c|}{ Controlled } \\
\hline $\begin{array}{l}\text { Industry and } \\
\text { Year }\end{array}$ & \multicolumn{8}{|c|}{ Fixed } \\
\hline Adj. R & \multicolumn{2}{|c|}{$9.28 \%$} & & & \multirow{2}{*}{\multicolumn{2}{|c|}{$9.29 \%$}} & \multicolumn{2}{|c|}{$9.24 \%$} \\
\hline \# of Samples & \multicolumn{6}{|c|}{7,257} & & \\
\hline
\end{tabular}

\begin{tabular}{|c|c|c|c|c|c|c|c|c|}
\hline \multicolumn{9}{|c|}{ Panel C: KOSDAQ } \\
\hline Variable & Estimate & t-value & Estimate & t-value & Estimate & t-value & Estimate & t-value \\
\hline Intercept & $1.533^{* *}$ & 2.48 & $1.360^{* *}$ & 2.25 & $1.501^{* *}$ & 2.43 & $1.331^{* *}$ & 2.21 \\
\hline OUTDIR & $0.679^{* * *}$ & 3.68 & $0.693^{* * *}$ & 3.75 & & & & \\
\hline$F R G N$ & 0.003 & 1.19 & & & 0.003 & 1.32 & & \\
\hline$M N G R$ & $-0.307^{*}$ & -1.85 & & & & & $-0.338^{* *}$ & -2.04 \\
\hline Control Var. & \multicolumn{8}{|c|}{ Controlled } \\
\hline \multicolumn{9}{|c|}{ Industry and Year } \\
\hline & \multicolumn{8}{|c|}{ Fixed } \\
\hline Adj. R & \multicolumn{2}{|c|}{$13.75 \%$} & \multicolumn{2}{|c|}{$13.72 \%$} & \multicolumn{2}{|c|}{$13.63 \%$} & \multicolumn{2}{|c|}{$13.65 \%$} \\
\hline \# of Samples & \multicolumn{8}{|c|}{10,928} \\
\hline
\end{tabular}

\section{CONCLUSIONS}

In previous chapters, we explored how the corporate governance influence companies' unfaithful disclosure and UDC designation/imposition of penalty points. Using percentage of outside directors, the percentage of foreign ownership and that of managerial ownership as a proxy for corporate governance and more detailed data of UDC, we conducted an empirical analysis examining the link between corporate governance and UDC designation/imposition of penalty points.

Information disclosure are the useful channels to communicate with outside information users to access companies' financial information; thereby, timely and accurate disclosure decrease information asymmetry and enable efficient allocation of resources. However, if reliability and accuracy of the information disclosure are not secured, information users cannot make reasonable decisions and have difficulties in assessing objective value of the companies based on such unreliable source of information.

In Korea, some research has been found in the field of finance and accounting that good corporate governance leads to increased level of disclosure (Lee \& Sohn 2005; Lee et al. 2012). It has also been conducted on unfaithful disclosure system and impacts of UDC designation for the capital market and company's stakeholders (Lee et al. 2008; Lee et al. 2012; Sohn et al. 2012). We used more detailed UDC data and focused on explaining the relationship between corporate governance and UDC designation and accumulated penalty points. To empirically test my hypotheses, we used firm-year forecast observations from 18,185 companies over the period from 2000 to 2015 . We find that there is significant negative association between the proportion of outside directors, an indicator of the board's independence, and UDC designation, among companies listed on both KOSPI and KOSDAQ. We interpret this result that outside director system checks and balances the management, thereby effectively playing the role of reducing errors in timeliness, accuracy and reliability of disclosed information. Regarding the percentage of foreign equity ownership showed statistically significant positive association with UDC designation and a significant positive association with the imposed and accumulated penalty points among KOSPI-listed companies. This may imply that foreign cannot effectively monitor and control the disclosure quality. Lastly, there was a significant positive association between the percentage of managerial ownership and UDC designation in the KOSDAQ market. 
This paper contributes to the existing literature by suggesting that corporate governance mechanism influence the designation as UDC and imposition penalty scores on UDC in Korea. In addition, while prior studies are mostly limited to the level of disclosures measured by the frequency of disclosure when it comes to explaining the relationship between corporate governance and the level of disclosure, this paper focused on a more detailed look by using unique unfaithful disclosure corporation data. We believe that our study sheds some lights on the impact of corporate governance mechanism on the quality of disclosure and effectiveness of corporate governance to monitor management actions in Korea's stock market.

\section{AUTHOR BIOGRAPHIES}

Boyoung Moon (1st author) is an assistant professor of School of Business Administration at Dankook University in Korea. Research interests include equity valuation, financial accounting, and auditing. E-mail: bymoon@dankook.ac.kr

Soo Yeon Park (corresponding author) is a researcher of Institute for Business Research \& Education at Korea University in Korea. Research interests include voluntary disclosures, and other financial \& managerial accounting issues. E-mail: sooyeonpark@korea.ac.kr

\section{REFERENCES}

Ajinkya, B., S. Bhojraj, \& P. Sengupta (2005). Association between outside directors, institutional investors and the properties of management earnings forecasts. Journal of Accounting Research, 43(3), 343-376.

Ashbaugh, H., D. W. Collins, \& R. LaFond (2006). The effects of corporate governance on firms' credit ratings. Journal of Accounting and Economics, 42, 203-243.

Baysinger, R.D. \& Butler, H.N. (1985). Corporate governance and the board of directors: Performance effects of changes in board composition. Journal of Law, Economics and Organization, 1, 101-124.

Bradbury, M. E. (1992). Voluntary disclosure of financial segment data: New Zealand evidence. Accounting and Finance, 32(1), 15-26.

Byun, H. Y., S. K. Kwak, \& L. S. Hwang (2008). The implied cost of equity capital and corporate governance practices. AsiaPacific Journal of Financial Studies, 37(1), 139-184.

Chen, A. \& B. Jaggi (2000). Association between independent non-executive directors, family control and financial disclosures in Hong Kong. Journal of Accounting and Public Policy, 19, 285-310.

Chung, R., S. Ho., \& J. B. Kim (2004). Ownership structure and the pricing discretionary accruals in Japan. Journal of International Accounting, Auditing \& Taxation, 13, 1-20.

Diamond, D. W., \& R. E. Verrecchia (1991). Disclosure, liquidity, and the cost of capital. The Journal of Finance, 46(4), 13251359.

Eng, L. \& Y. Mak (2003). Corporate governance and voluntary disclosure. Journal of Accounting and Public Policy, 22, $325-$ 345.

Fama, E. F., \& M. C. Jensen (1983). Separation of ownership and control. Journal of Law and Economics, 26(2), $301-325$.

Foster, G. (1986). Financial statement analysis. (Prentice Hall, Englewood Cliffs, N J).

Forker, J.J. (1992). Corporate governance and disclosure quality. Accounting and Business Research, 22(86), 111-124.

Hope, O.-K., \& Thomas, W. (2008). Managerial empire building and firm disclosure. Journal of Accounting Research, 46(3), 591-626.

Jensen, M. C., \& W. H. Meckling (1976). Theory of the firm: Managerial behavior, agency costs and ownership structure. Journal of Financial Economics, 3(4), 305-360.

Kim, C. S. (2006). Outside directors and firm value in Korea. Korean Journal of Finance, 19(2), 105-153.

Kim, D. S., \& Y. S. Cheon. (2004). Foreign investors vs. domestic investors, who are better informed investors? Asia-Pacific Journal of Financial Studies, 33(2), 1-44.

Kim, M. T., \& Kim, Y. H. (2007). The impacts of foreign ownership and outside directors on bond grading. Korean Accounting Review, 32(4), 29-58.

Kim, P. (2010). An empirical analysis on the relationship between foreign ownership and firm value in the KOSDAQ market. DaeHan Journal of Business, 23(6), 3427-3449.

Kim, S. I., \& Kwak, J. Y. (2013). Accounting earnings management of foreign investors in accordance with long or short-term investment preference. Accounting Information Review, 31(2), 235-261.

Lee, A. Y., S. B. Chun., \& S. U. Park (2008). The effect of unfaithful disclosure on the cost of debt. Korean Accounting Review, 33(1), 127-158.

Lee, H. D., Park, S. S., \& Choi, S. M. (2001). Financial activities capability survey of Korean companies. LG Economic Research Institute. 
Lee, J.W., \& S. Sohn (2005). An empirical analysis of the relationship between corporate governance and corporate disclosure practices in Korea. Korean Accounting Review, 30(3), 33-69.

Lee, M., Shim, H. S., \& Choi, J. H. (2012). Board characteristics and the frequency of disclosure of the firms belonging to large business groups. Korean Accounting Review, 37(2), 279-320.

Lee, M. G., Chang, S. J., \& Park, H. J. (2012). The effects of unfaithful disclosure on audit hours and audit fees. Korean Accounting Journal, 21(6), 1-30.

Lee, S. W., Kim, Y. C., \& Jung, T. S. (2010). The effects of internal control weakness and board of directors' characteristics on asset misappropriation. Korean Accounting Journal, 19(5), 89-123.

Lee, S. Y., Park, H. J., \& Lee, S. C. (2014). An empirical study on the stock price reaction to unfaithful disclosure and unfaithful disclosure penalty scores. Korean Management Review, 43, 387-413.

Mak. Y. (1991). Corporate characteristics and the voluntary disclosure of forecasts information: A study of New Zealand prospectuses. British Accounting Review, 23, 305-327.

Morck, R., Shleifer, A. \& Vishny, R. W. (1988). Management ownership and market valuation: An empirical analysis. Journal of Financial Economics, 20, 293-315.

Nagar, V., Nanda, D. \& Wysocki, P. (2003). Discretionary disclosure and stock-based incentives. Journal of Accounting and Economics, 34(1-3), 283-309.

Oh, H. M. \& Shin, H. Y. (2016). Voluntary Disclosure, information asymmetry and corporate governance after the adoption of IFRS. Accounting Information Review, 34(2), 159-188.

Park, K. S., \& Lee, E. J. (2006). The role of foreign investors on the management and corporate governance of Korean companies. Journal of Money and Finance, 20(2), 73-113.

Rho, J. H., Bae, G. S., \& Cheon, Y. (2003). Do firms with large agency costs choose high quality audits? A comparison of the audit quality between foreign-direct-investment-firms and local firms. Korean Accounting Review, 28(4), $203-230$.

Sachs \& Warner (1995). Economic reform and the process of global integration. Brookings Papers on Economic Activity. 1-118. Sepasi, S., Kazempour, M. \& Mansourlakoraj, R. (2016). Ownership structure and disclosure quality. Procedia Economics and Finance, 36, 108-112.

Sohn, S. (2001). Unfaithful disclosure and information effect. Yonsei Business Review, 38, 1-31.

Sohn, S. K., Chae, S. J., \& Oh, Y. (2012). The effect of unfaithful disclosure designation and unfaithful disclosure penalty points on internal accounting control review and audit opinion. Korean Accounting Review, 37(1), 1-40. 


\section{NOTES}

